\title{
Optimization of Chromium Removal by the Indigenous Bacterium Bacillus spp. REP02 Using the Response Surface Methodology
}

\author{
C. K. Venil, ${ }^{1}$ V. Mohan, ${ }^{2}$ P. Lakshmanaperumalsamy, ${ }^{3}$ and M. B. Yerima ${ }^{4}$ \\ ${ }^{1}$ Division of Food Microbiology and Biotechnology, Department of Food Science and Technology, Pondicherry University, \\ Pondicherry 605 014, India \\ ${ }^{2}$ Forest Pathology Laboratory, Forest Protection Division, Institute of Forest Genetics and Tree Breeding, \\ Coimbatore 641 002, Tamil Nadu, India \\ ${ }^{3}$ Karpagam University, Coimbatore 641 021, Tamil Nadu, India \\ ${ }^{4}$ Department of Microbiology, Faculty of Sciences, Usmanu Danfodiyo University Sokoto, Sokoto, Nigeria
}

Correspondence should be addressed to C. K. Venil, ckvenil@gmail.com

Received 5 July 2011; Accepted 17 August 2011

Academic Editors: D. Liu and D. A. Saffarini

Copyright ( $) 2011$ C. K. Venil et al. This is an open access article distributed under the Creative Commons Attribution License, which permits unrestricted use, distribution, and reproduction in any medium, provided the original work is properly cited.

\begin{abstract}
An indigenous bacterium, Bacillus REP02, was isolated from locally sourced chromium electroplating industrial effluents. Response surface methodology was employed to optimize the five critical medium parameters responsible for higher $\% \mathrm{Cr}^{2+}$ removal by the bacterium Bacillus REP02. A three-level Box-Behnken factorial design was used to optimize $\mathrm{K}_{2} \mathrm{HPO}_{4}$, yeast extract, $\mathrm{MgSO} 4, \mathrm{NH}_{4} \mathrm{NO}_{3}$, and dextrose for $\mathrm{Cr}^{2+}$ removal. A coefficient of determination $\left(R^{2}\right)$ value $(0.93)$, model $F$-value (3.92) and its low $P$-value $(F<0.0008)$ along with lower value of coefficient of variation (5.39) indicated the fitness of response surface quadratic model during the present study. At optimum parameters of $\mathrm{K}_{2} \mathrm{HPO}_{4}\left(0.6 \mathrm{gL}^{-1}\right)$, yeast extract $\left(5.5 \mathrm{gL}^{-1}\right), \mathrm{MgSO}_{4}\left(0.04 \mathrm{gL}^{-1}\right)$, $\mathrm{NH}_{4} \mathrm{NO}_{3}\left(0.20 \mathrm{~g} \mathrm{~L}^{-1}\right)$, and dextrose $\left(12.50 \mathrm{~g} \mathrm{~L}^{-1}\right)$, the model predicted $98.86 \% \mathrm{Cr}^{2+}$ removal, and experimentally, $99.08 \% \mathrm{Cr}^{2+}$ removal was found.
\end{abstract}

\section{Introduction}

Widespread industrial applications of chromium and the resultant effluent discharge affect the environment adversely [1]. Conventional chemical, physical methods (chemical precipitation, chemical oxidation or reduction, ion exchange, filtration, electrochemical treatment, reverse osmosis, membrane technologies, evaporation recovery, etc.), and activated sludge biological treatment for removal of chromium are generally efficient in removing the bulk of metal from solution at high or moderate concentrations, whereas they may be ineffective or extremely expensive especially when the metals in solution are at low concentration [2]. As a consequence, their limits (high cost, high reagent requirements, etc.) become more pronounced when voluminous effluents containing complexing organic matter and low metal contamination were to be treated. Compared with these conventional methods, biological treatment shows some advantages, such as low operation cost, steady effect, easy recovery of some valuable metals [3]; incidentally biotechnological approaches with right designs can succeed in treating such niches [4].

A wide variety of microorganisms such as bacteria, yeast, algae, protozoa, and fungi found in waters receiving industrial effluents, have developed the capabilities to protect themselves from heavy metal toxicity by various mechanisms such as adsorption, uptake, methylation, oxidation, and reduction. Many microorganisms have been reported to hold inbuilt competence to reduce the highly soluble and toxic $\mathrm{Cr}^{6+}$ to the less soluble and less toxic $\mathrm{Cr}^{3+}$, for example, Acinetobacter and Ochrobactrum [5], Arthrobacter [6], Pseudomonas sp. [7], Serratia marcescens [8], Ochrobactrum sp. [9], Bacillus sp. [10], Desulfovibrio vulgaris [11], and Cellulomonas spp. [12].

Among microorganisms, bacteria are better candidates for heavy metal removal as these are easy to culture, easy 
to handle and have very simple nutritional requirements. Several studies on metal removal by different bacterial species have been carried out by optimizing the medium parameters applying one variable at a time or response surface methodology (RSM). One variable at a time method is laborious, time consuming to perform experiments, not possible to obtain accurate optimum conditions and to detect the frequent interactions occurring between two or more factors $[13,14]$. On the other hand, RSM is a combination of mathematical and statistical techniques used for developing, improving, and optimizing the processes. It is used to evaluate the relative significance of several affecting factors even in the presence of complex interactions.

Although heavy metal removal efficiency of the microorganisms is a confirmed fact, there is possibility for existence of new microorganisms in local effluents because of the influence of the local socioeconomic factors over the heavy metal effluents of the area. The present study was aimed to isolate a potent indigenous bacterium from such locally sourced effluents from chromium electroplating industries and study its efficiency in chromium uptake under various interactive parameters by applying RSM.

\section{Materials and Methods}

2.1. Sampling. Effluent samples were collected locally in screw capped sterilized bottles from Roots Industries Pvt. Ltd., Kurudampalayam, Coimbatore 641017, Tamil Nadu, India that uses chromium for metal plating.

2.2. Isolation of Chromium Resistant Bacteria. For isolation of chromium-resistant bacteria, $100 \mu \mathrm{L}$ of the effluent sample was spread on Luria-Bertani (LB) agar plates. The medium was autoclaved at $121^{\circ} \mathrm{C}$ and $15 \mathrm{lbs}$ for $15 \mathrm{~min}$. The growth of the bacterial colonies was observed after $24 \mathrm{~h}$ of incubation at $37^{\circ} \mathrm{C}$. Effect of $\mathrm{Cr}^{6+}$ on the growth of bacterial isolates was determined in a minimal medium which contained (g/L): $\mathrm{NH}_{4} \mathrm{Cl}, 1.0 ; \mathrm{CaCl}_{2} \cdot \mathrm{H} 2 \mathrm{O}, 0.001 ; \mathrm{MgSO}_{4} \cdot 7 \mathrm{H}_{2} \mathrm{O}, 0.2$; $\mathrm{FeSO}_{4} \cdot 7 \mathrm{H}_{2} \mathrm{O}$, 0.001; sodium acetate, 5.0; yeast extract, 0.5; $\mathrm{K}_{2} \mathrm{HPO}_{4}, 0.5$ ( $\mathrm{pH} 7$ ) supplemented with $\mathrm{K}_{2} \mathrm{Cr}_{2} \mathrm{O}_{7}$ [15]. It was again incubated at $37^{\circ} \mathrm{C}$ for $24 \mathrm{~h}$. This process was repeated with successively higher concentrations of $\mathrm{Cr}^{6+}$, until the minimum inhibitory concentration (MIC) of bacterial isolate was obtained, and the isolate was identified as Bacillus spp. REP02.

2.3. Chromium Assay. $\mathrm{Cr}^{6+}$ concentrations was determined by 1-5 diphenylcarbazide method (EPA, 2006) using UVVis spectrophotometer [16] at $540 \mathrm{~nm}$. The initial and the final concentration of chromium used in batch mode studies were calculated by estimating the concentration of chromium spectrophotometrically. From the difference in concentration, the removal efficiencies of the bacteria was calculated.

2.4. Experimental Design. The Box-Behnken factorial design was used to optimize the $\mathrm{Cr}^{2+}$ removal efficiency of Bacillus sp. REP02. This experimental design consisting of three
TABLE 1: Independent variables and their levels in the experimental design.

\begin{tabular}{lccc}
\hline Independent variables $\left(\mathrm{g} \mathrm{L}^{-1}\right)$ & Symbols & -1 Level & +1 Level \\
\hline $\mathrm{K}_{2} \mathrm{HPO}_{4}$ & A & 0.2 & 1 \\
Yeast extract & B & 1 & 10 \\
$\mathrm{MgSO}_{4}$ & $\mathrm{C}$ & 0.04 & 0.4 \\
$\mathrm{NH}_{4} \mathrm{NO}_{3}$ & $\mathrm{D}$ & 0.2 & 1 \\
Dextrose & E & 5 & 20 \\
\hline
\end{tabular}

levels (low, medium and high coded as $-1,0$, and +1 ) in 46 runs were performed in duplicate to optimize the levels of five chosen key medium parameters, that is, $\mathrm{K}_{2} \mathrm{HPO}_{4}$, yeast extract, $\mathrm{MgSO}_{4}, \mathrm{NH}_{4} \mathrm{NO}_{3}$, and dextrose. For statistical calculations the five independent variables were designated as $X_{1}, X_{2}, X_{3}, X_{4}$, and $X_{5}$, respectively, and were coded according

$$
X_{i}=\frac{X_{i}-X_{0}}{\Delta X_{i}}
$$

where $X_{i}$ is the real value of an independent variable, $X_{0}$ is the real value of an independent variable at the centre point and $\Delta X_{i}$ is the step change value [17]. The lowest and highest levels of the variables were $\mathrm{K}_{2} \mathrm{HPO}_{4}(0.20$ to $\left.1.0 \mathrm{gL}^{-1}\right)$, yeast extract (1 to $\left.10 \mathrm{gL}^{-1}\right), \mathrm{MgSO}_{4}$ (0.04 to $\left.0.4 \mathrm{~g} \mathrm{~L}^{-1}\right), \mathrm{NH}_{4} \mathrm{NO}_{3}\left(0.2\right.$ to $\left.1.0 \mathrm{~g} \mathrm{~L}^{-1}\right)$, and dextrose (5 to $20 \mathrm{~g} \mathrm{~L}^{-1}$ ). The range of variables selected (Table 1) was based on preliminary experiments in which broad ranges were used and the range for each variable selected during the present study was the one in which metal removal was maximum. The metal removal efficiency of Bacillus sp. REP02 was multiply regressed with respect to the different parameters by the least square methods as follows:

$$
Y=\beta_{0}+\sum \beta_{i} x_{i}+\sum \beta_{i i} x_{i}^{2}+\sum \beta_{i j} x_{i} x_{j}
$$

where $Y$ is the predicted response variable, $\beta_{0}, \beta_{i}, \beta_{i i}$, and $\beta_{i j}$ are constant regression coefficients of the model, $x_{i}$ and $x_{j}(i=1,3 ; j=1,3, i 6.25 j)$ represent the independent variables in the form of coded values. The accuracy and fitness of the above model was evaluated by coefficient of determination $\left(R^{2}\right)$ and $F$ value. The predicted values for $\mathrm{Cr}^{2+}$ removal were obtained by applying quadratic model (Design Expert software version 7.1.5, Stat Ease). The optimum values of the variable parameters for metal removal were obtained by solving the regression equation, analyzing the contour plots and constraints for the variable parameters using the same software.

2.5. Validation Experiment. The mathematical model generated during RSM performance was validated by conducting experiments on given optimal medium setting.

\section{Results and Discussion}

Microbes can develop a high resistance to heavy metals by a variety of mechanisms to remove ions, such as adsorption to cell surfaces, complexation by exopolysaccharides, 
intracellular accumulation or precipitation $[18,19]$. That's why isolating microbes from polluted environments would represent an appropriate practice to select metal-resistant strains that could be used for heavy metal removal and bioremediation purposes $[4,20]$. The present study used a similar approach and isolated bacteria accordingly from the electroplating effluents.

Among the bacteria isolated from the electroplating effluents and selected for testing, Bacillus spp. REP02 was the only bacterium able to grow in vitro into the electroplating effluents, demonstrating a real potential to adaptation to this polluted environment. This characteristic made it potentially useful for both chromium uptake and biosorption in the inactivate state, which are the two main strategies for the bioremediation of effluents polluted by heavy metals.

Many sea weeds, bacteria, yeasts, and filamentous fungi have already been investigated for metal-binding capacities and bacteria seem among the most promising, since their cell wall surface contains many functional groups of carboxyl, hydroxyl, sulphydryl, amino groups and phosphate group of lipids, proteins and polysaccharides having ability to bind metal ions [21-23]. Nevertheless, most of these studies have been performed using synthetic metal solutions. On the other hand, this research using a bonafide electroplating effluent demonstrated the potential of Bacillus spp. REP02 to remove the chromium from electroplating effluent.

In this study, the combination of the five parameters investigated under batch studies, that is, $\mathrm{K}_{2} \mathrm{HPO}_{4}$, yeast extract, $\mathrm{MgSO}_{4}, \mathrm{NH}_{4} \mathrm{NO}_{3}$, and dextrose demonstrated maximum \% removal of chromium by Bacillus spp. REP02. Interactive effect of these five parameters confirmed their chromium removal efficiency. The results of 46 run BoxBehnken design for five medium parameters chosen for optimization of chromium removal are shown in Table 2. It shows the \% removal efficiency of Bacillus spp. REP02 ranging from $34.97 \%$ to $98.86 \%$ corresponding to the combined effect of the five parameters in their specific ranges. The experimental results suggest that these parameters strongly support the chromium removal by the isolate Bacillus spp. REP02. Lowest chromium removal efficiency of $34.97 \%$ was observed under the following conditions in the 4th run: $\mathrm{K}_{2} \mathrm{HPO}_{4}\left(0.6 \mathrm{~g} \mathrm{~L}^{-1}\right)$, yeast extract $\left(5.5 \mathrm{~g} \mathrm{~L}^{-1}\right), \mathrm{MgSO}_{4}$ $\left(0.22 \mathrm{~g} \mathrm{~L}^{-1}\right), \mathrm{NH}_{4} \mathrm{NO}_{3}\left(1 \mathrm{~g} \mathrm{~L}^{-1}\right)$, and dextrose $\left(5 \mathrm{~g} \mathrm{~L}^{-1}\right)$. Chromium removal efficiency above $98 \%$ was observed in the 25th run when the parameters were at $\mathrm{K}_{2} \mathrm{HPO}_{4}$ $\left(0.6 \mathrm{~g} \mathrm{~L}^{-1}\right)$, yeast extract $\left(5.5 \mathrm{gL}^{-1}\right), \mathrm{MgSO}_{4}\left(0.04 \mathrm{gL}^{-1}\right)$, $\mathrm{NH}_{4} \mathrm{NO}_{3}\left(0.2 \mathrm{~g} \mathrm{~L}^{-1}\right)$, and dextrose $\left(12.5 \mathrm{~g} \mathrm{~L}^{-1}\right)$. This suggests that $\mathrm{MgSO}_{4}, \mathrm{NH}_{4} \mathrm{NO}_{3}$, and dextrose had a profound influence on the chromium removal efficiency while interacting with other parameters at optimum levels.

On several occasions it has been reported that the cell wall of bacteria responds to the culture medium and other properties of the environment by greatly changing its composition and chemical-physical properties [24, 25]. Moreover, the $\mathrm{C}: \mathrm{N}$ ratio in the medium can affect the amount of structural compounds and other chemical groups of the cell wall [24]. In this study, Bacillus spp. REP02 cultured on the medium containing dextrose as carbon source and ammonium nitrate as nitrogen source displayed a higher chromium removal than that cultured on the medium containing other sources. This result is of great significance for the application of this method in industry, since dextrose is a low-cost material; its use as a source of carbon would reduce the generally very expensive metal removal.

The results obtained (Table 2) from Box-Behnken design fitted to a second order polynomial equation to explain the chromium removal efficiency of the five parameters is given in

$$
\begin{aligned}
Y= & +82.77-7.58 A-0.50 B-4.37 C-6.29 D+5.78 E \\
& +3.31 A B-0.020 A C-4.95 A D-2.29 A E+0.15 B C \\
& -13.20 B D-0.17 B E+7.19 C D-4.00 C E+13.00 D E \\
& -12.48 A^{2}-15.77 B^{2}-3.50 C^{2}-2.34 D^{2}-14.35 E^{2}
\end{aligned}
$$

where $Y$ is the predicted response (\% removal), $A, B, C, D$, and $E$ are the coded values of $\mathrm{K}_{2} \mathrm{HPO}_{4}$, yeast extract, $\mathrm{MgSO}_{4}$, $\mathrm{NH}_{4} \mathrm{NO}_{3}$, and dextrose, respectively.

Significance of each coefficient was determined by Student's $t$-test and $P$ values. Analysis of variance (ANOVA) results of this model are presented in Table 3. The value of $R^{2}$ and adjusted $R^{2}$ is close to 1.0 , which is very high and has advocated a high correlation between the observed and the predicted values. This means that regression model provides an excellent explanation of the relationship between independent variables (parameters) and the response (chromium removal).

Chromium removal efficiency up to $98.86 \%$ and the remaining left over of the chromium in the effluents show how well the model satisfies the assumptions of the analysis of variance. The model adequacy check is an important part of the data analysis procedure, as the approximating model would give poor or misleading results if it were an inadequate fit. This is done by looking at the residual plots, which are examined for the approximating model [26]. The significant value $(<0.05)$ revealed that the quadratic model is statistically significant for the response, and therefore, it can be used for further analysis. The normal probability and the internally studentized residuals plot are shown in Figure 1 for \% chromium removal efficiency. The internally studentized residuals measure the number of standard deviations separating the actual and predicted values. Figure 1 shows that neither response transformation was needed nor there was any apparent problem with normality.

Usually, it is essential to ensure that selected model is providing an adequate approximation to the real system. By applying the diagnostic plots such as the predicted versus actual value plot, the model adequacy can be judged.

3.1. Effect of Interactive Parameters. The experimental design employed with five process parameters to evaluate their effect showed highest efficiency of Bacillus spp. REP02 in chromium removal. To indicate the interactive effect of the five parameters on chromium removal, contour plots were generated. 
TABLE 2: Experimental design and results of the Box-Behnken design.

\begin{tabular}{|c|c|c|c|c|c|c|c|}
\hline \multirow[t]{2}{*}{ Run } & \multirow{2}{*}{$\begin{array}{c}A: \mathrm{K}_{2} \mathrm{HPO}_{4} \\
\left(\mathrm{~g} \mathrm{~L}^{-1}\right)\end{array}$} & \multirow{2}{*}{$\begin{array}{c}\text { B: Yeast extract } \\
\left(\mathrm{g} \mathrm{L}^{-1}\right)\end{array}$} & \multirow{2}{*}{$\begin{array}{c}C: \mathrm{MgSO}_{4} \\
\left(\mathrm{~g} \mathrm{~L}^{-1}\right)\end{array}$} & \multirow{2}{*}{$\begin{array}{c}D: \mathrm{NH}_{4} \mathrm{NO}_{3} \\
\left(\mathrm{~g} \mathrm{~L}^{-1}\right)\end{array}$} & \multirow{2}{*}{$\begin{array}{c}E: \text { Dextrose } \\
\left(\mathrm{g} \mathrm{L}^{-1}\right)\end{array}$} & \multicolumn{2}{|c|}{ Chromium \% } \\
\hline & & & & & & Experimental & Predicted \\
\hline 1 & 0.2 & 5.5 & 0.22 & 0.6 & 5 & 65.85 & 65.43 \\
\hline 2 & 0.2 & 5.5 & 0.22 & 0.6 & 20 & 87.08 & 81.58 \\
\hline 3 & 0.6 & 5.5 & 0.22 & 0.2 & 20 & 66.55 & 65.15 \\
\hline 4 & 0.6 & 5.5 & 0.22 & 1 & 5 & 34.97 & 35.00 \\
\hline 5 & 0.6 & 10 & 0.22 & 0.2 & 12.5 & 85.75 & 86.09 \\
\hline 6 & 0.6 & 1 & 0.04 & 0.6 & 12.5 & 56.97 & 68.53 \\
\hline 7 & 0.6 & 10 & 0.22 & 1 & 12.5 & 48.97 & 49.32 \\
\hline 8 & 0.6 & 5.5 & 0.22 & 1 & 20 & 69.76 & 68.55 \\
\hline 9 & 1 & 5.5 & 0.4 & 0.6 & 12.5 & 54.85 & 54.82 \\
\hline 10 & 1 & 5.5 & 0.22 & 0.6 & 5 & 37.09 & 40.32 \\
\hline 11 & 0.2 & 5.5 & 0.22 & 1 & 12.5 & 67.98 & 64.17 \\
\hline 12 & 0.6 & 10 & 0.4 & 0.6 & 12.5 & 65.97 & 64.03 \\
\hline 13 & 0.6 & 1 & 0.4 & 0.6 & 12.5 & 58.66 & 58.77 \\
\hline 14 & 0.6 & 5.5 & 0.22 & 0.6 & 12.5 & 85.08 & 79.48 \\
\hline 15 & 0.6 & 1 & 0.22 & 0.6 & 20 & 57.87 & 59.09 \\
\hline 16 & 0.6 & 5.5 & 0.04 & 1 & 12.5 & 68.98 & 67.81 \\
\hline 17 & 0.6 & 5.5 & 0.22 & 0.6 & 12.5 & 87.98 & 89.03 \\
\hline 18 & 0.6 & 5.5 & 0.04 & 0.6 & 5 & 54.09 & 59.51 \\
\hline 19 & 0.2 & 5.5 & 0.04 & 0.6 & 12.5 & 76.98 & 78.71 \\
\hline 20 & 0.2 & 1 & 0.22 & 0.6 & 12.5 & 65.54 & 65.90 \\
\hline 21 & 0.6 & 10 & 0.22 & 0.6 & 5 & 45.96 & 46.53 \\
\hline 22 & 0.2 & 10 & 0.22 & 0.6 & 12.5 & 65.86 & 68.27 \\
\hline 23 & 0.6 & 5.5 & 0.4 & 0.2 & 12.5 & 78.76 & 75.65 \\
\hline 24 & 1 & 1 & 0.22 & 0.6 & 12.5 & 37.98 & 34.13 \\
\hline 25 & 0.6 & 5.5 & 0.04 & 0.2 & 12.5 & 98.86 & 99.08 \\
\hline 26 & 0.2 & 5.5 & 0.4 & 0.6 & 12.5 & 56.98 & 60.01 \\
\hline 27 & 1 & 5.5 & 0.22 & 0.6 & 20 & 50.05 & 55.84 \\
\hline 28 & 0.6 & 5.5 & 0.04 & 0.6 & 20 & 88.76 & 79.07 \\
\hline 29 & 1 & 10 & 0.22 & 0.6 & 12.5 & 51.53 & 49.74 \\
\hline 30 & 0.6 & 1 & 0.22 & 1 & 12.5 & 74.65 & 77.26 \\
\hline 31 & 1 & 5.5 & 0.22 & 0.2 & 12.5 & 69.43 & 71.60 \\
\hline 32 & 0.6 & 5.5 & 0.22 & 0.6 & 12.5 & 76.38 & 72.96 \\
\hline 33 & 0.6 & 1 & 0.22 & 0.6 & 5 & 64.31 & 57.20 \\
\hline 34 & 1 & 5.5 & 0.22 & 1 & 12.5 & 53.86 & 49.12 \\
\hline 35 & 1 & 5.5 & 0.04 & 0.6 & 12.5 & 74.93 & 81.97 \\
\hline 36 & 0.6 & 10 & 0.22 & 0.6 & 20 & 38.85 & 37.75 \\
\hline 37 & 0.6 & 5.5 & 0.4 & 1 & 12.5 & 81.64 & 73.45 \\
\hline 38 & 0.6 & 5.5 & 0.22 & 0.2 & 5 & 83.75 & 79.58 \\
\hline 39 & 0.2 & 5.5 & 0.22 & 0.2 & 12.5 & 63.76 & 66.86 \\
\hline 40 & 0.6 & 5.5 & 0.22 & 0.6 & 12.5 & 79.05 & 82.77 \\
\hline 41 & 0.6 & 10 & 0.04 & 0.6 & 12.5 & 63.67 & 67.21 \\
\hline 42 & 0.6 & 5.5 & 0.22 & 0.6 & 12.5 & 83.61 & 83.60 \\
\hline 43 & 0.6 & 5.5 & 0.4 & 0.6 & 20 & 65.54 & 62.33 \\
\hline 44 & 0.6 & 1 & 0.22 & 0.2 & 12.5 & 58.65 & 58.25 \\
\hline 45 & 0.6 & 5.5 & 0.22 & 0.6 & 12.5 & 85.38 & 82.77 \\
\hline 46 & 0.6 & 5.5 & 0.4 & 0.6 & 5 & 46.86 & 48.76 \\
\hline
\end{tabular}


TABLE 3: Analysis of variance (ANOVA), regression coefficient estimate and test of significance for $\mathrm{Cr}^{2+}$ removal (response surface quadratic model).

\begin{tabular}{|c|c|c|c|c|c|}
\hline Source & Sum of squares & $\mathrm{df}$ & Mean square & $F$ value & $P$-value \\
\hline Model & 8067.895 & 20 & 403.39 & 3.92 & 0.0008 \\
\hline$A-\mathrm{K}_{2} \mathrm{HPO}_{4}$ & 918.2415 & 1 & 918.24 & 8.93 & 0.0062 \\
\hline$B$-Yeast extract & 4.070306 & 1 & 4.07 & 0.04 & 0.8439 \\
\hline$C-\mathrm{MgSO}_{4}$ & 306.075 & 1 & 306.08 & 2.98 & 0.0969 \\
\hline$D-\mathrm{NH}_{4} \mathrm{NO}_{3}$ & 633.7806 & 1 & 633.78 & 6.16 & 0.0201 \\
\hline E-Dextrose & 534.5344 & 1 & 534.53 & 5.20 & 0.0314 \\
\hline$A B$ & 43.75823 & 1 & 43.76 & 0.43 & 0.5202 \\
\hline$A C$ & 0.0016 & 1 & 0.00 & 0.00 & 0.9969 \\
\hline$A D$ & 97.91103 & 1 & 97.91 & 0.95 & 0.3386 \\
\hline$A E$ & 21.02223 & 1 & 21.02 & 0.20 & 0.6551 \\
\hline$B C$ & 0.093025 & 1 & 0.09 & 0.00 & 0.9762 \\
\hline$B D$ & 696.4321 & 1 & 696.43 & 6.77 & 0.0154 \\
\hline$B E$ & 0.112225 & 1 & 0.11 & 0.00 & 0.9739 \\
\hline$C D$ & 206.7844 & 1 & 206.78 & 2.01 & 0.1686 \\
\hline$C E$ & 63.92003 & 1 & 63.92 & 0.62 & 0.4380 \\
\hline$D E$ & 675.74 & 1 & 675.74 & 6.57 & 0.0168 \\
\hline$A^{2}$ & 1360.048 & 1 & 1360.05 & 13.22 & 0.0013 \\
\hline$B^{2}$ & 2170.927 & 1 & 2170.93 & 21.10 & 0.0001 \\
\hline$C^{2}$ & 106.6674 & 1 & 106.67 & 1.04 & 0.3183 \\
\hline$D^{2}$ & 47.96591 & 1 & 47.97 & 0.47 & 0.5010 \\
\hline$E^{2}$ & 1797.403 & 1 & 1797.40 & 17.47 & 0.0003 \\
\hline Residual & 2571.918 & 25 & 102.88 & & \\
\hline Lack of Fit & 2485.731 & 20 & 124.29 & 7.21 & 0.0188 \\
\hline Pure Error & 86.18655 & 5 & 17.24 & & \\
\hline Cor Total & 10639.81 & 45 & & & \\
\hline
\end{tabular}

$R^{2}: 0.93 ;$ Adj $R^{2}: 0.8649$; Pred $R^{2}: 0.0538 ;$ CV: 5.3 .

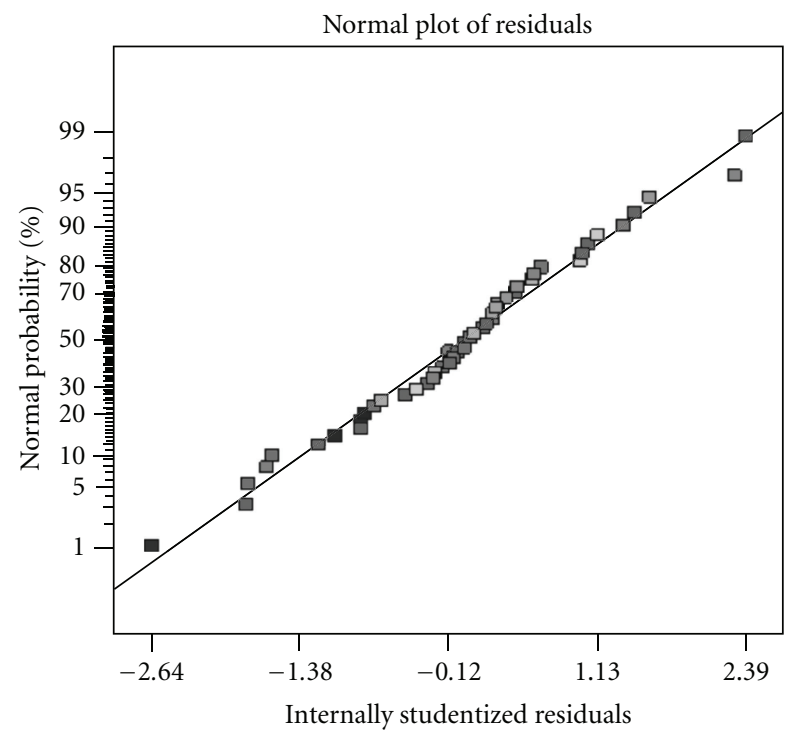

FIGURE 1: The internally studentized residuals and normal \% probability plot of $\mathrm{Cr}^{2+}$ removal by Bacillus spp. REP02.

3.2. Effect of $\mathrm{K}_{2} \mathrm{HPO}_{4}$ and Yeast Extract. The results of the RSM study on the combined effect of $\mathrm{K}_{2} \mathrm{HPO}_{4}$ and yeast extract in chromium removal are shown in the form of contour plot (Figure 2(a)). At $\mathrm{K}_{2} \mathrm{HPO}_{4}\left(0.75 \mathrm{~g} \mathrm{~L}^{-1}\right)$ and yeast extract $\left(6 \mathrm{~g} \mathrm{~L}^{-1}\right)$, the chromium removal efficiency was $77.31 \%$ which declines to $50.76 \%$ at $\mathrm{K}_{2} \mathrm{HPO}_{4}\left(0.90 \mathrm{~g} \mathrm{~L}^{-1}\right)$ and yeast extract $\left(1.5 \mathrm{gL}^{-1}\right)$, respectively. The optimum values of the parameters, namely, $\mathrm{K}_{2} \mathrm{HPO}_{4}$ and yeast extract can be analyzed by checking the maxima formed by the $X$ and $Y$ coordinates of the plot. Phosphate sources play a crucial role in cellular respiration and metabolism of the microbes which induces the microbe to uptake the metal ions [27]. Yeast extract was found to influence chromium removal more than the inorganic media components. This indicates that the optimized media composition varies greatly with respect to the desired response and application. The nutrient requirement for optimum chromium removal from the effluents depends on the nature of microbial species employed.

3.3. Effect of $\mathrm{K}_{2} \mathrm{HPO}_{4}$ and $\mathrm{MgSO}_{4}$. The combined effects of $\mathrm{K}_{2} \mathrm{HPO}_{4}$ and $\mathrm{MgSO}_{4}$ in chromium removal are shown in the form of contour plot (Figure 2(b)). The chromium removal efficiency was $59.89 \%$ at $\mathrm{K}_{2} \mathrm{HPO}_{4}\left(1.0 \mathrm{gL}^{-1}\right)$ and $\mathrm{MgSO}_{4}\left(0.4 \mathrm{~g} \mathrm{~L}^{-1}\right)$, and the \% chromium removal efficiency increased to $80.20 \%$ at $\mathrm{K}_{2} \mathrm{HPO}_{4}\left(0.5 \mathrm{gL}^{-1}\right)$ and $\mathrm{MgSO}_{4}$ $\left(0.3 \mathrm{~g} \mathrm{~L}^{-1}\right)$. There are very limited data in the literature 


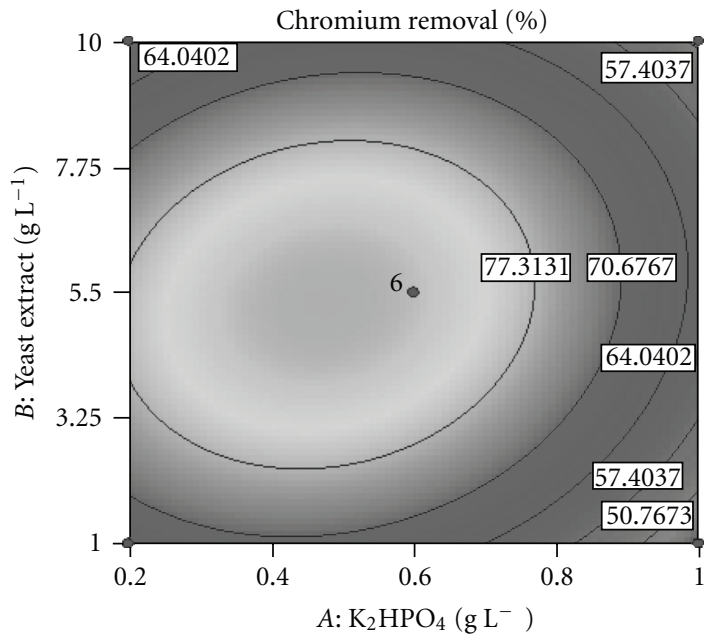

(a)

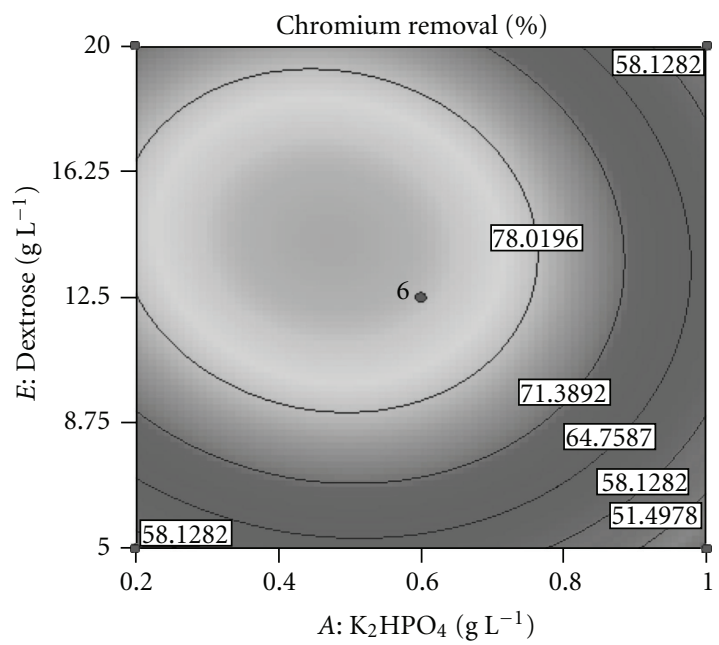

(c)

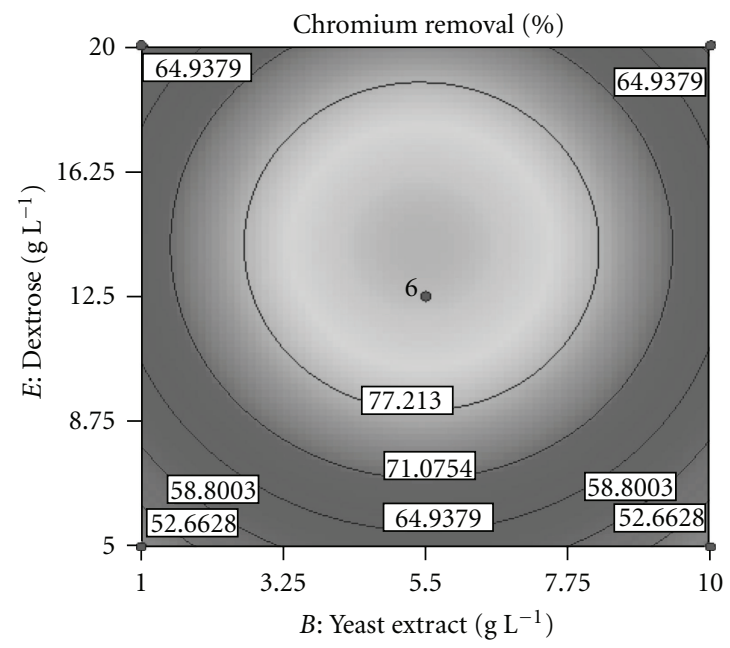

(e)

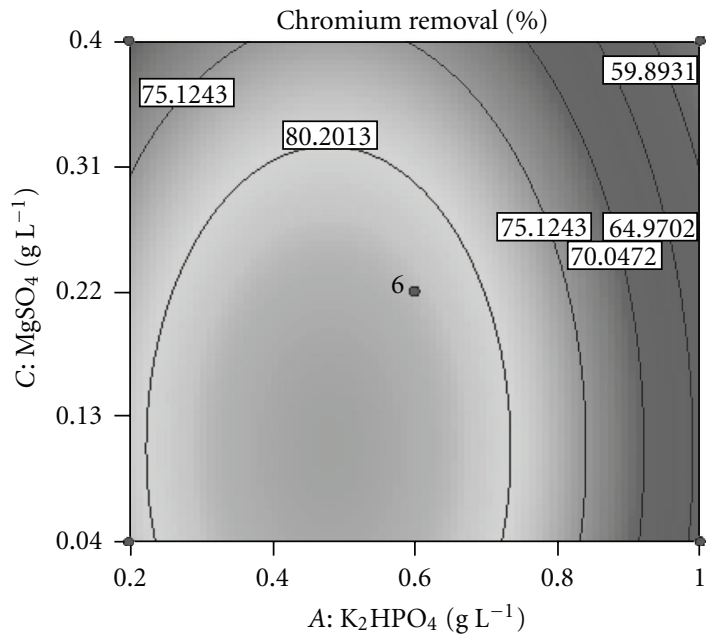

(b)

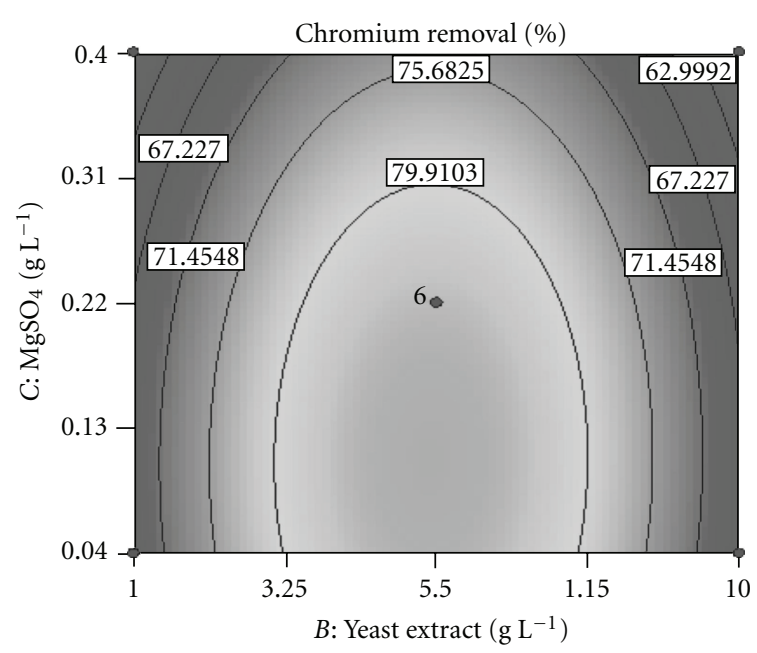

(d)

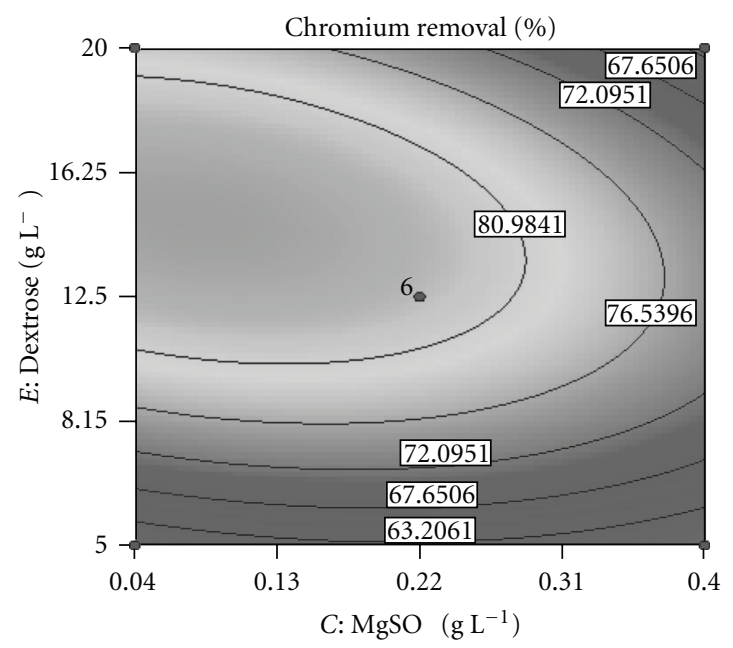

(f)

FIgURE 2: Contour surface plot for the removal of chromium by Bacillus spp. REP02-A function of $\mathrm{K}_{2} \mathrm{HPO}_{4}$ and yeast extract. Contour surface plot for the removal of chromium by Bacillus spp. REP02-A function of $\mathrm{K}_{2} \mathrm{HPO}_{4}$ and $\mathrm{MgSO}_{4}$. Contour surface plot for the removal of chromium by Bacillus spp. REP02-A function of $\mathrm{K}_{2} \mathrm{HPO}_{4}$ and dextrose. Contour surface plot for the removal of chromium by Bacillus spp. REP02-A function of yeast extract and $\mathrm{MgSO}_{4}$. Contour surface plot for the removal of chromium by Bacillus spp. REP02-A function

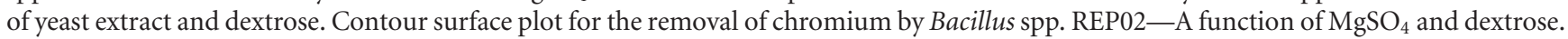


concerning the influence of microbes on the effectiveness of phosphate amendments for metal removal. Bacillus spp. REP02 was able to utilize $\mathrm{Mg}^{2+}$ ions when the concentration of this ion was low in simple medium, thereby stimulating chromium removal. Bacteria may enhance the uptake of heavy metals by increasing $\mathrm{Mg}^{2+}$-soluble fraction by dissolution and desorption due to the secretion of protons [28].

3.4. Effect of $\mathrm{K}_{2} \mathrm{HPO}_{4}$ and Dextrose. The results of the BoxBehnken study on the combined effect of $\mathrm{K}_{2} \mathrm{HPO}_{4}$ and dextrose in chromium removal are shown in the form of contour plot (Figure $2(\mathrm{c})$ ). At $\mathrm{K}_{2} \mathrm{HPO}_{4}\left(0.95 \mathrm{~g} \mathrm{~L}^{-1}\right)$ and dextrose $\left(5.5 \mathrm{~g} \mathrm{~L}^{-1}\right)$, the chromium removal efficiency was $51.49 \%$ which increased to $78.01 \%$ at $\mathrm{K}_{2} \mathrm{HPO}_{4}\left(0.75 \mathrm{~g} \mathrm{~L}^{-1}\right)$ and dextrose $\left(14 \mathrm{~g} \mathrm{~L}^{-1}\right)$, respectively. The optimum values of the parameters namely, $\mathrm{K}_{2} \mathrm{HPO}_{4}$ and dextrose, can be analyzed by checking the maxima formed by the $X$ and $Y$ coordinates of the plot.

The efficiency of dextrose in the medium can be explained by the fact that Bacillus spp. REP02 is a heterotroph and is capable of utilizing dextrose as a carbon source. Most of the Bacillus spp. utilizes glucose as a nutrient substrate [29]. Our result clearly indicates that Bacillus spp. REP02 is capable of gaining energy from dextrose as an electron donor and ferric iron as an electron acceptor. Under oxygenlimiting conditions, ferric iron can be reduced to ferrous iron. The dissimulatory ferric iron reduction under anoxic state runs usually according to the following reaction stated by Coates et al. [30]

$$
\begin{aligned}
\mathrm{C}_{6} \mathrm{H}_{12} \mathrm{O}_{6}+2 \mathrm{H}_{2} \mathrm{O}+8 \mathrm{Fe}^{3+} \\
\stackrel{\text { Bacteria }}{\longrightarrow} 2 \mathrm{CH}_{3} \mathrm{COOH}+2 \mathrm{CO}_{2}+8 \mathrm{Fe}^{2+}+8 \mathrm{H}^{+} .
\end{aligned}
$$

3.5. Effect of Yeast Extract and $\mathrm{MgSO}_{4}$. The combined effects of yeast extract and $\mathrm{MgSO}_{4}$ in chromium removal are shown in the form of contour plot (Figure 2(d)). The chromium removal efficiency was $62.99 \%$ at yeast extract $\left(1.0 \mathrm{~g} \mathrm{~L}^{-1}\right)$ and $\mathrm{MgSO}_{4}\left(0.4 \mathrm{~g} \mathrm{~L}^{-1}\right)$, and the \% chromium removal efficiency increased to $79.91 \%$ at yeast extract $\left(5.5 \mathrm{~g} \mathrm{~L}^{-1}\right)$ and $\mathrm{MgSO}_{4}$ $\left(0.3 \mathrm{~g} \mathrm{~L}^{-1}\right)$.

It has been shown that for some microbes, highnitrogen conditions repressed metal removal to some degree. However, nutrient limitation, especially nutrient nitrogen stimulated removal of heavy metals in most species investigated to date [31].

3.6. Effect of Yeast Extract and Dextrose. The interactive effect of yeast extract and dextrose in chromium removal was shown in the form of contour plot in Figure 2(e). At yeast extract $\left(1.75 \mathrm{~g} \mathrm{~L}^{-1}\right)$ and dextrose $\left(6.0 \mathrm{~g} \mathrm{~L}^{-1}\right)$, the chromium removal efficiency was $52.66 \%$ which increases to $77.21 \%$ at yeast extract $\left(5.5 \mathrm{~g} \mathrm{~L}^{-1}\right)$ and dextrose $\left(10 \mathrm{~g} \mathrm{~L}^{-1}\right)$, respectively. The optimum values of the parameters, namely, yeast extract and dextrose can be analyzed by checking the maxima formed by the $X$ and $Y$ coordinates of the plot.

It was observed that the propensity of Bacillus spp. REP02 to chromium was dramatically enhanced by the increase of yeast extract strength. The chromium ions have a strong affinity for organic materials such as yeast extract. Thus, there are two possible explanations for the toxicity decrease of chromium when increasing yeast extract strength: the organic matter reacts with chromium ions to form compounds that are less toxic than the ions themselves, and/or the ions adsorbed on the surface of particles are rendered less toxic [32].

The increase of dextrose strength influences the chromium removal by Bacillus spp. REP02. This is probably due to the increase of metabolic activity. It was found that the chromium transport into the bacterial cell depends on energy, therefore, it is glucose dependent [33]. Thus, at high dextrose strength, chromium removal was enhanced.

3.7. Effect of $\mathrm{MgSO}_{4}$ and Dextrose. The combined effects of $\mathrm{MgSO}_{4}$ and dextrose in chromium removal are shown in the form of contour plot (Figure 2(f)). The chromium removal efficiency was $63.20 \%$ at $\mathrm{MgSO}_{4}\left(0.22 \mathrm{~g} \mathrm{~L}^{-1}\right)$ and dextrose $\left(5.0 \mathrm{~g} \mathrm{~L}^{-1}\right)$, and the $\%$ chromium removal efficiency increased to $80.98 \%$ at $\mathrm{MgSO}_{4}\left(0.25 \mathrm{~g} \mathrm{~L}^{-1}\right)$ and dextrose $\left(14 \mathrm{~g} \mathrm{~L}^{-1}\right)$, respectively.

The occurrence of binding chromium ions in an ionrich medium might be explained by the binding constants of various ligands that could be responsible for the heavy metal binding. The binding constants for various functional groups such as carboxylates, sulfur groups and amino groups have an overall higher binding affinity for the various metal ions studied [34]. Because of the binding constants, heavy metal binding to the various functional groups have higher stability constants, and it stands to reason that the metals would bind before the hard cations would. This would explain the specificity of chromium binding.

3.8. Validation of the Model. The maximum experimental response for chromium removal was $98.86 \%$, whereas predicted response was $99.08 \%$ indicating a strong agreement between them. The optimum values of the tested variables for maximum chromium removal by Bacillus spp. REP02 were $\mathrm{K}_{2} \mathrm{HPO}_{4}\left(0.6 \mathrm{~g} \mathrm{~L}^{-1}\right)$, yeast extract $\left(5.5 \mathrm{~g} \mathrm{~L}^{-1}\right), \mathrm{MgSO}_{4}$ $\left(0.04 \mathrm{~g} \mathrm{~L}^{-1}\right), \mathrm{NH}_{4} \mathrm{NO}_{3}\left(0.2 \mathrm{~g} \mathrm{~L}^{-1}\right)$, and dextrose $\left(12.5 \mathrm{~g} \mathrm{~L}^{-1}\right)$ as shown in perturbation graph (Figure 3 ).

In an attempt to optimize industrial conditions for chromium removal, scale-up study was carried out in a jar fermentor by using medium under optimum conditions. The results are encouraging (99.05\%) for optimization under pilot scale or industrial scale conditions, which could eventually reach out to actual industrial applications after due scientific compatibility study.

\section{Concluding Remarks}

In the present research, a potent indigenous bacterium Bacillus spp. REP02 was isolated from locally sourced electroplating effluents and its potential to uptake chromium tested by employing response surface methodology. This design helped in locating the optimum levels of the most significant medium parameters which contribute to the 


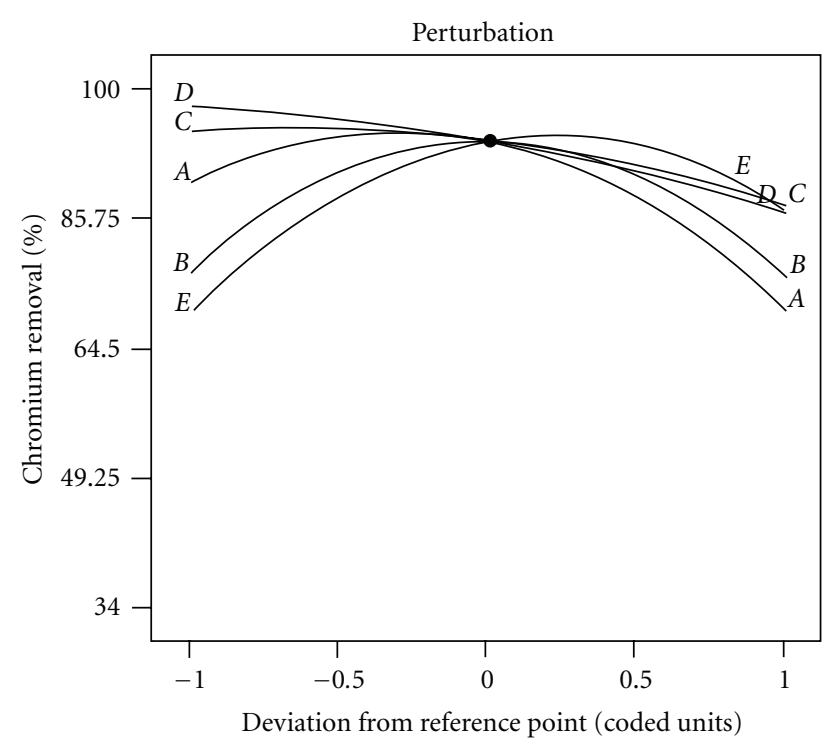

Chromium

Actual factors

$$
\begin{array}{llll}
\text { A: } \mathrm{K}_{2} \mathrm{HPO}_{4} & 0.6 \mathrm{~g} \mathrm{~L}^{-1} & D: \mathrm{NH}_{4} \mathrm{NO}_{3} & 0.2 \mathrm{~g} \mathrm{~L}^{-1} \\
\text { B: Yeast extract } & 5.5 \mathrm{~g} \mathrm{~L}^{-1} & \text { E: Dextrose } & 12.5 \mathrm{~g} \mathrm{~L}^{-1} \\
\text { C: } \mathrm{MgSO}_{4} & 0.04 \mathrm{~g} \mathrm{~L}^{-1} & &
\end{array}
$$

Figure 3: Perturbation graph showing the optimum values of the medium components.

maximum metal removal. RSM, when employed, not only demonstrated increased metal removal efficiency of the test organism at the optimized conditions but also proved to be simple, efficient, and time and material saving. The test organism was quite capable in $\mathrm{Cr}^{2+}$ removal from electroplating effluents and thus has the potential to be exploited for treatment of chromium containing industrial effluents before their discharge into water bodies.

\section{Acknowledgments}

The authors wish to acknowledge the kind cooperation provided by Tamil Nadu Pollution Control Board, Coimbatore, Tamil Nadu, India, and Roots Industries Pvt. Ltd., Coimbatore, Tamil Nadu, India, to undertake this study. The authors also wish to thank Bharathiar University, Coimbatore, Tamil Nadu, India, and Institute of Forest Genetics and Tree Breeding, Coimbatore, Tamil Nadu, India, for providing the infrastructure facilities for this study.

\section{References}

[1] A. Agrawal, V. Kumar, and B. D. Pandey, "Remediation options for the treatment of electroplating and leather tanning effluent containing chromium-a review," Mineral Processing and Extractive Metallurgy Review, vol. 27, no. 2, pp. 99-130, 2006.

[2] S. S. Ahluwalia and D. Goyal, "Microbial and plant derived biomass for removal of heavy metals from wastewater," Bioresource Technology, vol. 98, no. 12, pp. 2243-2257, 2007.
[3] A. Rehman and A. R. Shakoori, "Heavy metal resistant Chlorella spp., isolated from tannery effluents, and their role in remediation of hexavalent chromium in industrial wastewater," Bulletin of Environmental Contamination and Toxicology, vol. 66, pp. 542-547, 2001.

[4] A. Malik, "Metal bioremediation through growing cells," Environment International, vol. 30, no. 2, pp. 261-278, 2004.

[5] R. Francisco, M. C. Alpoim, and P. V. Morais, "Diversity of chromium-resistant and -reducing bacteria in a chromiumcontaminated activated sludge," Journal of Applied Microbiology, vol. 92, no. 5, pp. 837-843, 2002.

[6] M. Megharaj, S. Avudainayagam, and R. Naidu, "Toxicity of hexavalent chromium and its reduction by bacteria isolated from soil contaminated with tannery waste," Current Microbiology, vol. 47, no. 1, pp. 51-54, 2003.

[7] M. Rajkumar, R. Nagendran, K. J. Lee, and W. H. Lee, "Characterization of a novel $\mathrm{Cr}^{6+}$ reducing Pseudomonas sp. with plant growth-promoting potential," Current Microbiology, vol. 50, no. 5, pp. 266-271, 2005.

[8] V. L. Campos, R. Moraga, J. Yánez, C. A. Zaror, and M. A. Mondaca, "Chromate reduction by Serratia marcescens isolated from tannery effluent," Bulletin of Environmental Contamination and Toxicology, vol. 75, no. 2, pp. 400-406, 2005.

[9] U. Thacker and D. Madamwar, "Reduction of toxic chromium and partial localization of chromium reductase activity in bacterial isolate DM1," World Journal of Microbiology and Biotechnology, vol. 21, no. 6-7, pp. 891-899, 2005.

[10] R. Elangovan, S. Abhipsa, B. Rohit, P. Ligy, and K. Chandraraj, "Reduction of $\mathrm{Cr}(\mathrm{VI})$ by a Bacillus sp," Biotechnology Letters, vol. 28, no. 4, pp. 247-252, 2006.

[11] F. Goulhen, A. Gloter, F. Guyot, and M. Bruschi, "Cr(VI) detoxification by Desulfovibrio vulgaris strain Hildenborough: microbe-metal interactions studies," Applied Microbiology and Biotechnology, vol. 71, no. 6, pp. 892-897, 2006.

[12] S. Viamajala, W. A. Smith, R. K. Sani et al., "Isolation and characterization of $\mathrm{Cr}(\mathrm{VI})$ reducing Cellulomonas spp. from subsurface soils: implications for long-term chromate reduction," Bioresource Technology, vol. 98, no. 3, pp. 612-622, 2007.

[13] B. L. Liu and Y. M. Tzeng, "Optimization of growth medium for the production of spores from Bacillus thuringiensis using response surface methodology," Bioprocess Engineering, vol. 18, no. 6, pp. 413-418, 1998.

[14] S. Moyo, B. A. Gashe, E. K. Collison, and S. Mpuchane, "Optimising growth conditions for the pectinolytic activity of Kluyveromyces wickerhamii by using response surface methodology," International Journal of Food Microbiology, vol. 85, no. 1-2, pp. 87-100, 2003.

[15] P. Pattanapipitpaisal, N. L. Brown, and L. E. Macaskie, "Chromate reduction and 16s rRNA identification of bacteria isolated from a $\mathrm{Cr}(\mathrm{VI})$-contaminated site," Applied Microbiology and Biotechnology, vol. 57, no. 1-2, pp. 257-261, 2001.

[16] "EPA, Method 7196A, Chromium Hexavalent (Colorimetric)," 2006, http://www.epa.gov/sw-846/pdfs/7196a.pdf .

[17] K. K. Doddapaneni, R. Tatineni, R. Potumarthi, and L. N. Mangamoori, "Optimization of media constituents through response surface methodology for improved production of alkaline proteases by Serratia rubidaea," Journal of Chemical Technology and Biotechnology, vol. 82, no. 8, pp. 721-729, 2007.

[18] G. Massaccesi, M. C. Romero, M. C. Cazau, and A. M. Bucsinszky, "Cadmium removal capacities of filamentous soil fungi isolated from industrially polluted sediments, in La Plata 
(Argentina)," World Journal of Microbiology and Biotechnology, vol. 18, no. 9, pp. 817-820, 2002.

[19] P. Saxena, A. K. Bhattacharyya, and N. Mathur, "Nickel tolerance and accumulation by filamentous fungi from sludge of metal finishing industry," Geomicrobiology Journal, vol. 23, no. 5, pp. 333-340, 2006.

[20] L. zucconi, C. Ripa, F. Alianiello, A. Benedetti, and S. Onofri, "Lead resistance sorption accumulation in a Paecilomyces lilacinus strain," Biology and Fertility of Soils, vol. 37, no. 1, pp. 17-22, 2003.

[21] Y. Sag, "Biosorption of heavy metals by fungal biomass and modeling of fungal biosorption: a review," Separation and Purification Methods, vol. 30, no. 1, pp. 1-48, 2001.

[22] S. Deng and Y. P. Ting, "Polyethylenimine-modified fungal biomass as a high-capacity biosorbent for $\mathrm{Cr}(\mathrm{VI})$ anions: sorption capacity and uptake mechanisms," Environmental Science and Technology, vol. 39, no. 21, pp. 8490-8496, 2005.

[23] R. Kumar, N. R. Bishnoi, Garima, and K. Bishnoi, "Biosorption of chromium(VI) from aqueous solution and electroplating wastewater using fungal biomass," Chemical Engineering Journal, vol. 135, no. 3, pp. 202-208, 2008.

[24] P. Žnidaršič, N. Marošek, and A. Pavko, "Chitin contents in different morphological forms of Rhizopus nigricans," Folia Microbiologica, vol. 44, no. 5, pp. 557-560, 1999.

[25] M. Nemčovič and V. Farkaš, "Cell-wall composition and polysaccharide synthase activity changes following photoinduction in Trichoderma viride," Acta Biologica Hungarica, vol. 52, no. 2-3, pp. 281-288, 2001.

[26] G. Box and W. G. Hunter, Statistics for Experiments: An Introduction to Design, Data Analysis and Model Building, chapter 10, Wiley, New York, NY, USA, 1978.

[27] S. Nasseri, M. Mazaheri Assadi, M. Noori Sepehr, K. H. Rostami, M. Sharit, and K. Nadafi, "Chromium removal from Tanning effluent using biomass of Aspergillus oryzae," Pakistan Journal of Biological Sciences, vol. 5, no. 10, pp. 1056-1059, 2002.

[28] A. S. Knox, R. L. Brigmon, D. I. Kaplan, and M. H. Paller, "Interactions among phosphate amendments, microbes and uranium mobility in contaminated sediments," Science of the Total Environment, vol. 395, no. 2-3, pp. 63-71, 2008.

[29] J. S. Zhao, D. Manno, C. Beaulieu, L. Paquet, and J. Hawari, "Shewanella sediminis sp. nov., a novel $\mathrm{Na}+$ - requiring and hexahydro-1,3,5-trinitro-1,3,5-triazine-degrading bacterium from marine sediment," International Journal of Systematic and Evolutionary Microbiology, vol. 55, no. 4, pp. 1511-1520, 2005.

[30] J. D. Coates, T. Councell, D. J. Ellis, and D. R. Lovley, "Carbohydrate oxidation coupled to Fe(III) reduction, a novel form of anaerobic metabolism," Anaerobe, vol. 4, no. 6, pp. 277-282, 1998.

[31] P. C. Leung and S. B. Pointing, "Effect of different carbon and nitrogen regimes on poly R decolorization by white-rot fungi," Mycological Research, vol. 106, no. 1, pp. 86-92, 2002.

[32] M. M. K. Bagy, H. M. M. El-Sharouny, and A. A. ElShanawany, "Effect of $\mathrm{pH}$ and organic matter on the toxicity of heavy metals to growth of some fungi," Folia Microbiologica, vol. 36, no. 4, pp. 367-374, 1991.

[33] S. Mariano-da-Silva, S. L. de Oliveira, C. A. O. Leite et al., "Effect of $\mathrm{pH}$, dextrose and yeast extract on cadmium toxicity on Saccharomyces cerevisiae PE-2," Ciencia e Tecnologia de Alimentos, vol. 29, no. 2, pp. 295-299, 2009.

[34] A. E. Martell and R. M. Smith, Critical Stability Constants: Other Organic Ligands, vol. 3, Plenum Press, London, UK, 1977. 

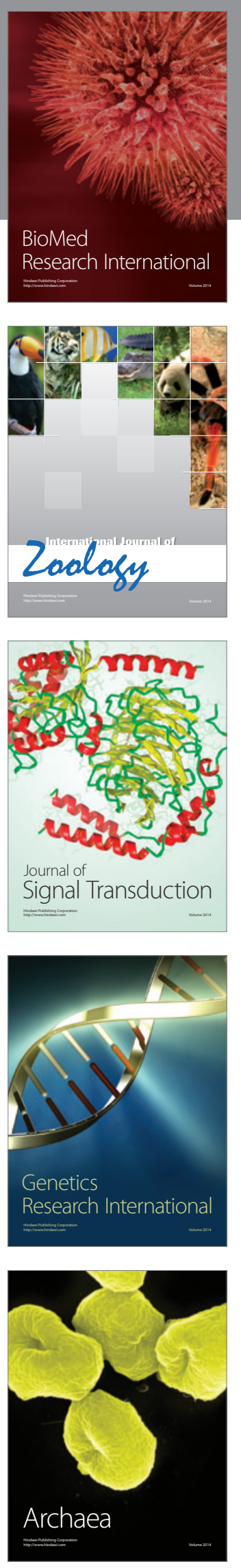
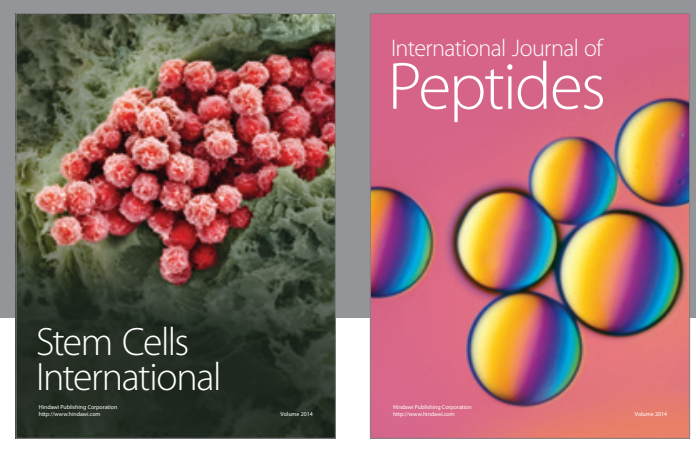

Submit your manuscripts at

http://www.hindawi.com
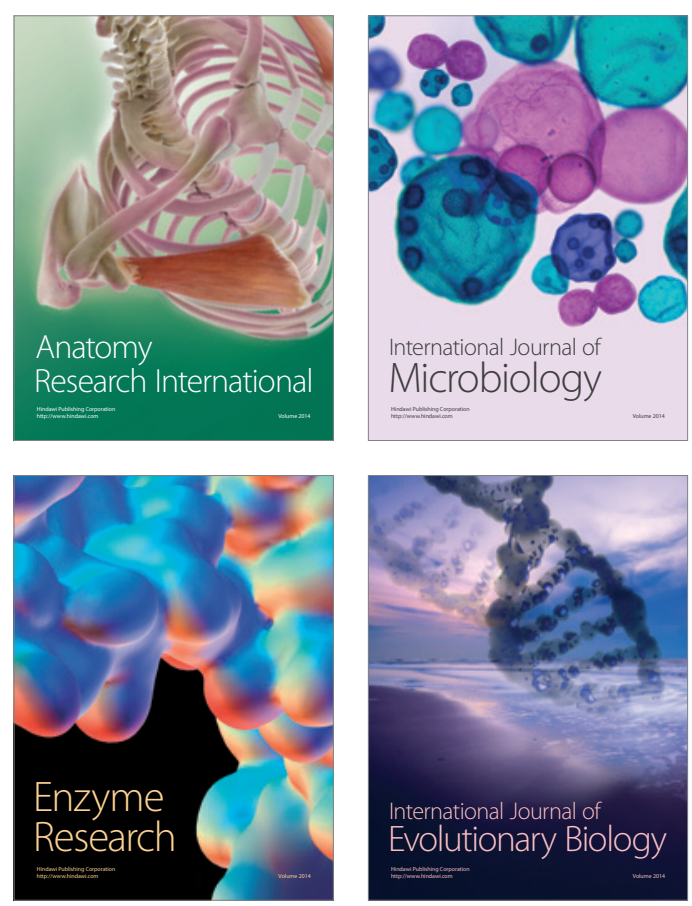
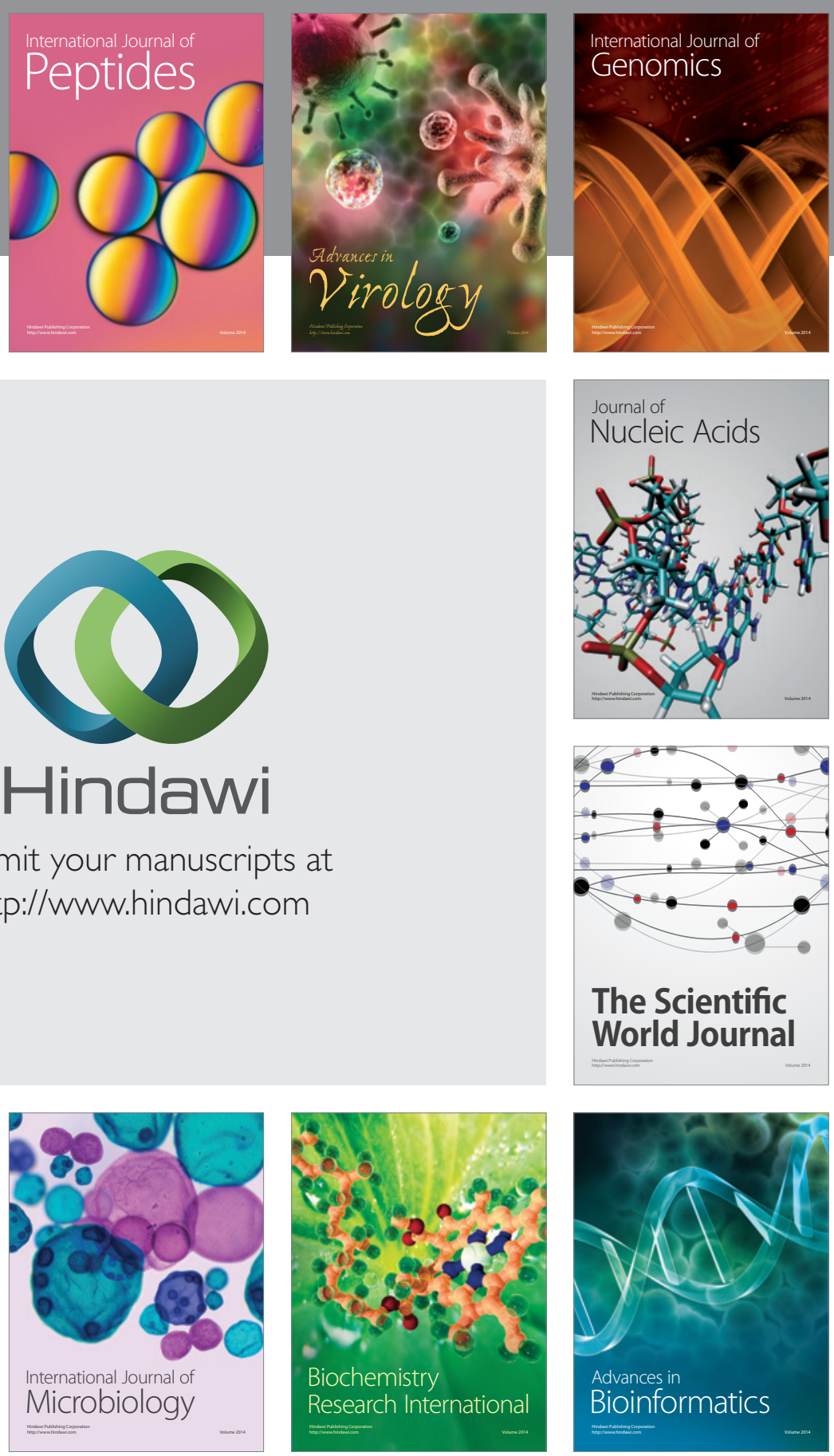

The Scientific World Journal
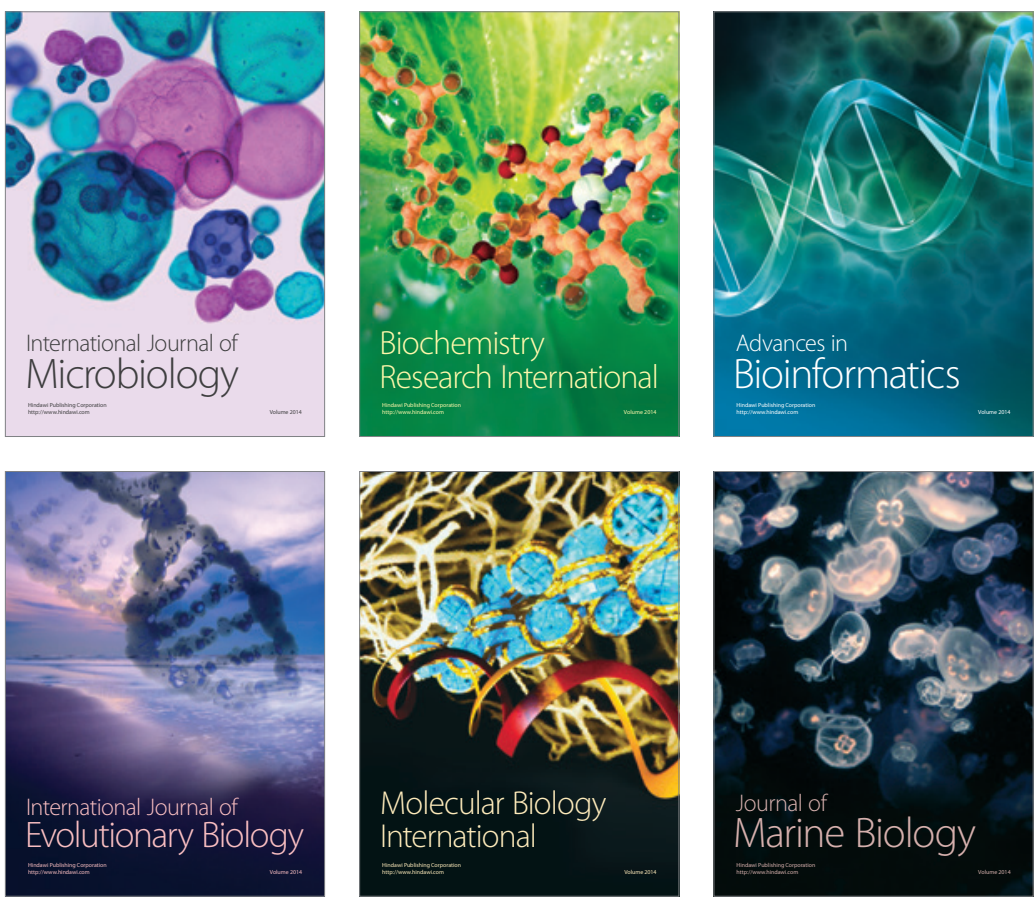